\title{
PENGARUH PENGGUNAAN MEDIA KOMIK TERHADAP HASIL BELAJAR SISWA KELAS X SMA NEGERI 3 PONTIANAK PADA MATERI LARUTAN ELEKTROLIT DAN NONELEKTROLIT
}

\author{
Eny Enawaty, Hilma Sari \\ Pendidikan Kimia, FPMIPA, Universitas Tanjungpura
}

\begin{abstract}
The purposes of the research is to know the effect using media of comic toward student achievement learning in class X SMA Negeri 3 Pontianak for electrolit solution and non electrolit solution. The research uses experiment method and design research is "Pretest Posttest Control Group Design”. The subject research are student calss $X E$ and $X F$, using purposive sampling to take the sample. The technique is used to gather the data is student achievement. Based on the data analisis using U-Mann Whitney test, $5 \%$ level signification is found that $Z$ count=-5,56 $\quad Z$ tabel -1,96, there is the difference students learning achievement between using comic media and praktikum metod. There are 96,97\% student get higger learning achievement and get the KKM. The Effect size is 1,82, means learning using comic media give big effect 46,56\% towards the higger student achievement student class X SMA Negeri 3 Pontianak. The respon 30 students class XE towards learning electrolit solution and non electrolit solution using media of comic is $95,87 \%$. This is shows that learning using comic media is effective to teach electrolit solution and non electrolit solution in class X SMA Negeri 3 Pontianak.
\end{abstract}

Keywords : electrolit solution and non electrolit solution, comic media, praktikum

Dewasa ini telah terjadi
perkembangan informasi, ilmu
pengetahuan, dan teknologi, sistem
pendidikan pun dituntut untuk dapat
merespon dan menyesuaikan
perkembangan yang terjadi. Seiring
dengan peranan dunia pendidikan
maka proses dan model pembelajaran
perlu terus diperbaharui. Model
pembelajaran itu banyak jenisnyaya,
setiap model pembelajaran sangat
ditentukan oleh tujuan pembelajaran
dan kemampuan guru dalam
mengelola proses pembelajaran.
Penyajian mata pelajaran sains
menuntut seorang pengajar harus

memiliki strategi belajar mengajar yang menarik dan dapat meningkatkan motivasi siswa untuk belajar, sehingga sajian yang disampaikan oleh guru bukanlah suatu sajian yang dangkal dan tidak mempunyai arti bagi siswa. Ketepatan guru dalam memvariasikan strategi belajar mengajar pada penyampaian materi, akan dapat merangsang siswa untuk terlibat dalam kegiatan belajar mengajar, sehingga apa yang didapat siswa bukanlah suatu kegiatan yang sia-sia atau yang tidak mempunyai arti bagi mereka. 
Materi larutan elektrolit dan nonelektrolit merupakan salah satu materi kimia yang harus dikuasai dan dipahami oleh siswa karena materi ini merupakan materi prasyarat untuk mempelajari materi sifat koligatif larutan dan elektrokimia. Berdasarkan hasil wawancara kepada guru mata pelajaran kimia di kelas X SMA Negeri 3 Pontianak, diketahui bahwa metode yang sering digunakan untuk materi ini adalah metode praktikum. Metode ini memiliki kelemahan yaitu memerlukan waktu yang lama dan pada saat praktikum siswa terkesan kurang serius (bercanda) sehingga diperlukan pengelolaan kelas yang baik.. Dari hasil belajar siswa, berupa nilai ulangan harian materi larutan elektrolit dan nonelektrolit diketahui bahwa dengan metode praktikum ini sebagian besar siswa masih belum bisa mencapai Kriteria Ketuntasan Minimal (KKM), yaitu 63. Guru kimia di kelas X SMA Negeri 3 Pontianak, jarang menggunakan media pembelajaran dalam mengajar selain papan tulis dan buku pelajaran kimia. Padahal media atau alat bantu dapat membantu siswa untuk memahami suatu konsep, dan membuat mereka menyenangi pembelajarannya.

Salah satu alternatif media yang dapat digunakan dalam pembelajaran kimia di kelas adalah komik. Komik adalah suatu bentuk media komunikasi visual yang mempunyai kekuatan untuk menyampaikan informasi secara popular dan mudah dimengerti. Hal ini dimungkinkan karena komik memadukan kekuatan gambar dan tulisan, yang dirangkai dalam suatu alur cerita gambar membuat informasi lebih mudah diserap. Teks membuatnya lebih dimengerti, dan alur membuatnya lebih mudah untuk diikuti dan diingat. Komik dapat menjadi media pembelajaran yang sangat efektif, sebagai contoh untuk menjelaskan konsep-konsep yang sangat abstrak dan memerlukan objek yang konkrit pada beberapa mata pelajaran, misalkan fisika, kimia atau matematika. Di lapangan, peneliti melihat bahwa siswa lebih menyenangi membaca komik dibandingkan dengan buku pelajaran. Berdasarkan hasil angket yang disebarkan kepada siswa kelas $\mathrm{X}$ SMA Negeri 3 pontianak sebanyak 3 kelas, bahwa sebesar $68,52 \%$ siswa menyatakan senang membaca komik. Ketika ditanya bagaimana pendapat mereka jika materi pelajaran kimia dikemas dalam bentuk komik sebesar $71,88 \%$ siswa menyambut positif dan setuju dengan ide tersebut.

Tujuan umum penelitian ini untuk mengetahui pengaruh penggunaan media komik terhadap hasil belajar siswa kelas x sma negeri 3 pontianak pada materi larutan elektrolit dan nonelektrolit. Tujuan penelitian ini :1) Untuk menentukan ada atau tidak perbedaan hasil belajar siswa kelas $\mathrm{X}$ SMA Negeri 3 Pontianak pada materi larutan elektrolit dan nonelektrolit yang diajarkan dengan menggunakan media komik dan yang diajarkan dengan metode praktikum. 2) Untuk menentukan besar pengaruh pembelajaran menggunakan media komik terhadap hasil belajar siswa pada materi larutan elektrolit dan nonelektrolit. 3) Untuk mengetahui respon siswa terhadap pembelajaran materi larutan elektrolit dan nonelektrolit dengan menggunakan media komik. 
Kata media berasal dari bahasa latin dan merupakan bentuk jamak dari kata medium yang berarti perantara atau pengantar. Media adalah semua bentuk perantara yang digunakan oleh manusia untuk menyampaikan atau menyebarkan ide, gagasan atau pendapat sehingga ide, gagasan atau pendapat yang dikemukakan itu sampai kepada penerima yang dituju. Asosiasi Pendidikan Nasional (National Education Association / NEA) mendefinisikan media sebagai bentuk-bentuk komunikasi baik tercetak maupun audiovisual serta peralatannya. Media adalah alat bantu apa saja yang dijadikan sebagai penyalur pesan guna mencapai tujuan pengajaran. Berdasarkan beberapa pengertian ini, dapat disimpulkan bahwa media adalah suatu alat yang digunakan sebagai alat bantu untuk menyampaikan informasi dalam proses pembelajaran. Pembelajaran dengan media akan terjadi apabila ada komunikasi antara penerima pesan dengan sumber / penyalur pesan lewat media tersebut.

Dalam dunia pendidikan, media dimanfaatkan untuk menyampaikan materi pembelajaran. Media yang digunakan harus disesuaikan dengan isi dan tujuan pembelajaran yang ingin dicapai agar proses belajar mengajar dapat terlaksana secara maksimal. Media pembelajaran adalah seperangkat alat pembelajaran yang digunakan oleh guru dalam menyampaikan materi pelajaran. Perangkat media yang digunakan oleh guru harus berfungsi sebagai sarana untuk mempermudah pemahaman siswa terhadap materi yang disampaikan oleh guru. Tujuan yang ingin dicapai dari media pembelajaran adalah terjadinya proses belajar pada diri siswa sehingga dapat menambah efektivitas komunikasi dan interaksi antara pengajar dan siswa. Kriteria yang paling utama dalam pemilihan media bahwa media harus disesuaikan dengan tujuan pembelajaran atau kompetensi yang ingin dicapai. Contohnya adalah bila tujuan atau kompetensi siswa bersifat menghafalkan kata-kata tentunya media audio yang tepat untuk digunakan. Jika tujuan atau kompetensi yang dicapai bersifat memahami isi bacaan maka media cetak yang lebih tepat digunakan. Kalau tujuan pembelajaran bersifat motorik (gerak dan aktivitas), maka media film dan video bisa digunakan. Di samping itu, terdapat kriteria lainnya yang bersifat melengkapi (komplementer), seperti biaya; ketepatgunaan; keadaan siswa; ketersediaan; dan mutu teknis.

Media yang digunakan juga harus sesuai dengan tingkat kemampuan siswa, dimana siswa mengenal dan memahami media tersebut, artinya siswa dapat memahami materi pelajaran dengan mudah melalui media yang tepat. Selain itu, di dalam proses pembelajaran dengan menggunakan media, guru harus melibatkan siswa ketika menyimpulkan materi pembelajaran. Hal ini dapat dilakukan dengan menanyakan kepada siswa manfaat dan kesulitan yang mereka alami selama proses pembelajaran.

Komik adalah suatu bentuk seni yang menggunakan gambar-gambar tidak bergerak yang disusun sedemikian rupa sehingga membentuk jalinan cerita. Biasanya, komik dicetak di atas kertas dan dilengkapi dengan teks. komik memanfaatkan 
ruang dalam media gambar untuk meletakkan gambar demi gambar sehingga membentuk suatu alur cerita yang utuh. Komik adalah suatu kartun yang mengungkapkan suatu karakter dan memerankan cerita dalam urutan yang erat dan merupakan bentuk berita bergambar, terdiri dari berbagai situasi dan kadangkala bersifat humor. Komik merupakan salah satu media foto atau gambar yang cocok dan sesuai untuk diterapkan dalam pembelajaran kimia. Pembelajaran dengan media komik kimia bisa menarik minat belajar siswa sehingga ketuntasan belajar bisa tercapai.

Komik merupakan media, media penyampaian ide, gagasan bahkan kebebasan berpikir. Komik untuk informasi pendidikan, baik cerita maupun desainnya dirancang khusus untuk penyampaian pesan-pesan pendidikan. Inti pesan harus dapat diterima dengan jelas dan alur ceritanya juga harus menarik bagi pembaca. Komik dapat dipakai untuk menolong siswa dalam pembelajaran pada hampir semua topik, misalnya a) mengenal konsep, b) belajar berhitung, c) mengenal lingkungan dan alam sekitar, d) membantu untuk memahami cerita, e) mendorong minat baca. Pendekatan visualisasi dengan komik biasanya digunakan untuk menarik minat baca siswa dan mempermudah siswa dalam memahami materi yang akan disampaikan.

Komik selain berfungsi sebagai media hiburan, juga dapat dipergunakan secara efektif dalam upaya membangkitkan minat baca, mengembangkan perbendaharaan kata-kata dan keterampilan membaca serta dapat dijadikan media efektif untuk tujuan pembelajaran. Untuk pembelajaran di sekolah tentu dipilih komik yang dapat mendidik, dapat menimbulkan gairah belajar pada siswa, komik yang lucu, dan komik yang dikenal oleh siswa yang disesuaikan dengan dunianya. Komik yang dibuat oleh peneliti, dipakai untuk membantu siswa dalam mengenal konsep dan mengenal lingkungan dan alam sekitar.

Pembelajaran adalah proses interaksi peserta didik dengan pendidik dan sumber belajar pada suatu lingkungan belajar. Adapun tahap-tahap pengajaran materi larutan elektrolit dan nonelektrolit dengan menggunakan media komik adalah sebagai berikut, Kegiatan awal : 1) membuka pertemuan dengan salam, 2) guru memberikan motivasi dan apersepsi kepada siswa, 3) menginformasikan materi yang akan dibahas, 4) menyampaikan tujuan pembelajaran, 5) guru membagi siswa ke dalam beberapa kelompok kecil secara heterogen (sebangku). Kegiatan inti : 1) guru membagikan komik materi larutan elektrolit dan nonelektrolit kepada setiap kelompok siswa, 2) guru memberikan pengarahan atau petunjuk dalam mempelajari media tersebut, 3) siswa ditugaskan untuk menjawab pertanyaan yang ada di media sesuai petunjuk, 4) guru memberikan kesempatan kepada siswa untuk bertanya. Kegiatan penutup : 1) guru bersama siswa membuat kesimpulan terhadap jawaban yang diberikan siswa, 2) guru meninggalkan kelas dan mengucapkan salam. Tahap-tahap pembelajaran dengan metode praktikum adalah sebagai berikut, kegiatan awal: 1) guru mengucapkan salam, 2) guru melakukan apersepsi, 3) guru menginformasikan materi 
larutan elektrolit dan non elektrolit yang akan dipelajari, 4) guru membagi siswa menjadi beberapa kelompok. Kegiatan inti : 1) guru membagikan LKS kepada siswa, 2) guru memberikan pengarahan tentang penggunaan LKS, 3) guru meminta siswa melakukan praktikum sesuai dengan petunjuk dalam LKS, 4) guru meminta siswa membuat laporan hasil pengamatan di LKS. Kegiatan penutup : 1) guru mengarahkan siswa untuk membuat kesimpulan tentang materi yang telah dibahas, 2) guru memberikan PR, 3) guru meminta siswa untuk mempelajari materi selanjutnya di rumah.

Bentuk penelitian yang digunakan dalam penelitian ini adalah penelitian eksperimen. Jenis eksperimen yang digunakan adalah eksperimen semu (Quasi Experimental Research). Peneliti akan mencoba mengungkapkan akibat perlakuan pengajaran dengan metode praktikum untuk kelas kontrol dan membandingkannya dengan kelas eksperimen yang diajar dengan menggunakan media komik. rancangan penelitian ini adalah cara pre-test post-test control group design. Populasi dalam penelitian ini adalah siswa kelas X SMA Negeri 3 Pontianak tahun ajaran 2008/2009 yang terdiri atas 3 kelas, yaitu : kelas XD sebanyak 36 siswa, kelas XE sebanyak 32 siswa, dan kelas XF sebanyak 32 siswa. Sampel dari penelitian ini terdiri dari 2 kelas. Adapun pengambilan sampel dilakukan dengan teknik purposive sampling. Dari populasi yang terdiri dari 3 kelas akan diambil 2 kelas yang memiliki rata-rata nilai ulangan kimia semester I hampir sama yaitu, kelas XE dan XF. Dalam menentukan kelas eksperimen dan kelas kontrol dilakukan pengundian. Hasilnya, yang dijadikan kelas kontrol adalah XF dan kelas eksperimen XE.

Untuk keperluan pengumpulan data penelitian, maka peneliti akan menggunakan teknik pengukuran. Adapun tes yang digunakan dalam penelitian ini adalah tes tertulis yang berbentuk essay. Tujuan dari pemberian angket respon dalam penelitian ini adalah untuk mengetahui respon siswa terhadap pembelajaran menggunakan media komik. Perhitungan angket respon dalam penelitian ini menggunakan skala likert.

Hipotesis dalam penelitian ini adalah " Tidak terdapat perbedaan hasil belajar siswa kelas X SMA Negeri 3 Pontianak pada materi larutan elektrolit dan nonelektrolit yang diajarkan dengan menggunakan media komik dan yang diajarkan dengan metode praktikum".

Dalam penelitian ini yang menjadi kelas kontrol adalah kelas $\mathrm{X}$ F. Kelas ini diberikan pembelajaran dengan metode praktikum. Jumlah siswa di kelas kontrol ada 31 orang. Namun, terdapat satu orang siswa yang tidak diolah datanya karena tidak mengikuti pretest. Jadi, jumlah siswa yang diolah datanya sebanyak 30 siswa.

Tabel 1 menunjukkan bahwa rata-rata pretest siswa kelas kontrol adalah 22,6 dan posttest siswa pada kelas kontrol adalah 30,6. Jadi, ratarata perubahan skor adalah sebesar 7,67. Berdasarkan nilai pretest dan posttest, seluruh siswa mengalami peningkatan hasil belajar. Dari 30 siswa, sebanyak 24 siswa (80 \%) yang memenuhi stándar nilai Kriteria Ketuntasan Minimal (63). Sedangkan 
6 siswa (20\%) lainnya, tidak memenuhi standar KKM.

Kelas eksperimen adalah kelas XE diberikan pembelajaran dengan menggunakan media komik. Jumlah siswa di kelas eksperimen ada 32 orang. Namun, terdapat 2 orang siswa yang tidak diolah datanya karena tidak mengikuti posttest. Jadi, jumlah siswa yang diolah datanya sebanyak 30 siswa.

Tabel 1 Pretest dan Posttest Kelas Kontrol .

\begin{tabular}{|c|c|c|c|c|c|c|}
\hline \multirow[b]{2}{*}{ No } & \multirow{2}{*}{$\begin{array}{l}\text { Kode } \\
\text { Siswa }\end{array}$} & \multicolumn{3}{|c|}{ Skor } & \multicolumn{2}{|c|}{ Nilai (1-100) } \\
\hline & & Pre test & Post test & $\begin{array}{c}\text { Peruba } \\
\text { han }\end{array}$ & Pre test & Post test \\
\hline 1. & $\mathrm{H}_{1}$ & 21 & 32 & 11 & 50 & 76,19 \\
\hline 2. & $\mathrm{H}_{2}$ & 22 & 31 & 9 & 52,38 & 73,81 \\
\hline 3. & $\mathrm{H}_{3}$ & 18 & 35 & 17 & 42,86 & 83,33 \\
\hline 4. & $\mathrm{H}_{4}$ & 17 & 33 & 16 & 40,48 & 78,57 \\
\hline 5. & $\mathrm{H}_{5}$ & 21 & 26 & 5 & 50 & 61,90 \\
\hline 6. & $\mathrm{H}_{6}$ & 27 & 32 & 5 & 64,23 & 76,19 \\
\hline 7. & $\mathrm{H}_{7}$ & 28 & 35 & 7 & 66,67 & 83,33 \\
\hline 8. & $\mathrm{H}_{8}$ & 21 & 36 & 15 & 50 & 85,71 \\
\hline 9. & $\mathrm{H}_{9}$ & 23 & 26 & 3 & 54,76 & 61,90 \\
\hline 10. & $\mathrm{H}_{10}$ & 34 & 35 & 1 & 80,95 & 83,33 \\
\hline 11. & $\mathrm{H}_{11}$ & 20 & 28 & 8 & 47,62 & 66,67 \\
\hline 12. & $\mathrm{H}_{12}$ & 21 & 25 & 4 & 50 & 59,52 \\
\hline 13. & $\mathrm{H}_{13}$ & 23 & 33 & 10 & 54,14 & 78,57 \\
\hline 14. & $\mathrm{H}_{14}$ & 28 & 29 & 1 & 66,67 & 69,05 \\
\hline 15. & $\mathrm{H}_{15}$ & 32 & 32 & 0 & 76,19 & 76,19 \\
\hline 16. & $\mathrm{H}_{16}$ & 20 & 30 & 11 & 47,62 & 71,43 \\
\hline 17. & $\mathrm{H}_{17}$ & 19 & 30 & 10 & 45,24 & 71,43 \\
\hline 18. & $\mathrm{H}_{18}$ & 34 & 38 & 4 & 80,95 & 90,48 \\
\hline 19. & $\mathrm{H}_{19}$ & 18 & 21 & 3 & 42,86 & 50 \\
\hline 20. & $\mathrm{H}_{20}$ & 23 & 27 & 4 & 54,76 & 64,23 \\
\hline 21. & $\mathrm{H}_{21}$ & 24 & 34 & 10 & 57,14 & 80,95 \\
\hline 22. & $\mathrm{H}_{22}$ & 18 & 25 & 7 & 42,86 & 59,52 \\
\hline 23. & $\mathrm{H}_{23}$ & 23 & 32 & 9 & 54,76 & 76,19 \\
\hline 24. & $\mathrm{H}_{24}$ & 15 & 35 & 10 & 35,72 & 83,33 \\
\hline
\end{tabular}




\begin{tabular}{|c|c|c|c|c|c|c|}
\hline 25. & $\mathrm{H}_{25}$ & 20 & 24 & 4 & 47,62 & 57,14 \\
\hline 26. & $\mathrm{H}_{26}$ & 23 & 30 & 7 & 54,76 & 71,43 \\
\hline 27. & $\mathrm{H}_{27}$ & 25 & 33 & 8 & 59,52 & 78,57 \\
\hline 28. & $\mathrm{H}_{28}$ & 18 & 30 & 12 & 42,86 & 71,43 \\
\hline 29. & $\mathrm{H}_{29}$ & 19 & 31 & 12 & 45,24 & 73,81 \\
\hline 30. & $\mathrm{H}_{30}$ & 23 & 30 & 7 & 54,76 & 71,43 \\
\hline & Jumlah & 678 & 918 & 230 & 1613,62 & 2185,63 \\
\hline & Rata-rata & 22,6 & 30,6 & 7,67 & 53,79 & $\mathbf{7 2 , 8 5}$ \\
\hline & SD & 4,79 & 4.00 & 4,38 & & \\
\hline \multicolumn{7}{|c|}{ Keterangan: $\quad$ Tidak Memenuhi KKM } \\
\hline
\end{tabular}

Tabel 2 menunjukkan bahwa rata-rata skor pretest siswa kelas eksperimen adalah 15,12 dan skor posttest siswa pada kelas eksperimen adalah 31,8. Rata-rata perubahan skor pretest dan posttest adalah sebesar 16,37. Seluruh siswa pada kelas eksperimen mengalami peningkatan hasil belajar dan hampir seluruhnya $(96,67 \%)$ memenuhi standar nilai Kriteria Ketuntasan Minimal (63). Hanya 1 orang siswa $(3,33 \%)$ yang tidak memenuhi standar nilai KKM.

Berdasarkan data tabel 1 dan tabel 2 terlihat bahwa rata-rata skor pretest kelas kontrol lebih tinggi daripada kelas eksperimen dengan selisih 7,48. Selanjutnya, untuk mengetahui apakah terdapat perbedaan yang signifikan antara kemampuan awal siswa pada kelas kontrol dan kelas eksperimen, maka dilakukan analisis secara statistik terhadap data tersebut.

Adapun langkah pertama yang dilakukan adalah dengan menguji normalitas skor pre-test pada kelas kontrol dan kelas eksprimen. Dari hasil uji normalitas skor pre-test kedua kelas tersebut, diperoleh bahwa kedua kelas tersebut tidak berdistribusi normal. Karena kedua kelas tidak berdistribusi normal maka dilanjutkan dengan uji statistik nonparametrik menggunakan uji U Mann Whitney. Dari hasil uji ini diperoleh data $Z_{\text {hitung }}$ $=-5,52$ dengan $Z_{\text {tabel }}(\alpha=5 \%)$ sebesar $\pm 1,96$ Karena $-Z_{\text {hitung }}<$ $\mathrm{Z}_{\text {tabel}}$, maka $\mathrm{H}_{0}$ ditolak dan $\mathrm{Ha}$ diterima. Hal ini berarti terdapat perbedaan yang signifikan antara kemampuan awal siswa pada kelas kontrol dan kelas eksprimen.

Dari hasil uji hipotesis $U$ mann Whitney terhadap selisih skor pretest dan post-test kelas control dan eksperimen diperoleh $\mathrm{Z}$ hitung sebesar -5,56 dengan $Z$ tabel $(\alpha=$ $5 \%$ ) sebesar $\pm 1,96$. Karena $-Z$ hitung $<-\mathrm{Z}$ tabel $(-5,56<1,96)$, maka $\mathrm{H}_{0}$ ditolak dan Ha diterima. Hal ini berarti terdapat perbedaan yang signifikan antara hasil belajar siswa kelas kontrol yang diajar menggunakan metode praktikum dengan kelas eksperimen yang diajar menggunakan media komik.

Untuk mengetahui seberapa besar pengaruh pembelajaran dengan menggunakan media komik terhadap hasil belajar siswa pada materi larutan elektrolit dan nonelektrolit, maka digunakan rumus effect size. Dari hasil perhitungan di dapat effect 
size sebesar 1,82 diklasifikasikan tinggi. Hal ini menunjukkan bahwa pembelajaran dengan menggunakan media komik memiliki pengaruh yang tinggi terhadap hasil belajar dalam materi larutan elektrolit dan non elektrolit di kelas X SMA Negeri 3 Pontianak.

Hasil angket 30 orang siswa

kelas XE SMA Negeri 3 Pontianak

Tabel 2 Pretest dan Posttest Kelas Eksperimen.

\begin{tabular}{|l|l|l|l|l|l|l|}
\hline No & $\begin{array}{l}\text { Kode } \\
\text { Siswa }\end{array}$ & $\begin{array}{l}\text { Skor } \\
\text { test }\end{array}$ & $\begin{array}{l}\text { Post } \\
\text { test }\end{array}$ & $\begin{array}{l}\text { Peru } \\
\text { baha } \\
\text { n }\end{array}$ & $\begin{array}{l}\text { Pre } \\
\text { test }\end{array}$ & $\begin{array}{l}\text { Post } \\
\text { test }\end{array}$ \\
\hline 1. & $\mathrm{~S}_{1}$ & 13 & 31 & 8 & 30,96 & 73,81 \\
\hline 2. & $\mathrm{~S}_{2}$ & 17 & 34 & 17 & 40,48 & 80,95 \\
\hline 3. & $\mathrm{~S}_{3}$ & 16 & 36 & 20 & 38,10 & 85,71 \\
\hline 4. & $\mathrm{~S}_{4}$ & 13 & 32 & 19 & 30,96 & 76,19 \\
\hline 5. & $\mathrm{~S}_{5}$ & 11 & 32 & 21 & 26,20 & 76,19 \\
\hline 6. & $\mathrm{~S}_{6}$ & 12 & 28 & 16 & 28,58 & 66,67 \\
\hline 7. & $\mathrm{~S}_{7}$ & 14 & 33 & 19 & 33,34 & 78,57 \\
\hline 8. & $\mathrm{~S}_{8}$ & 14 & 35 & 21 & 33,34 & 83,33 \\
\hline 9. & $\mathrm{~S}_{9}$ & 18 & 30 & 12 & 42,86 & 71,43 \\
\hline 10. & $\mathrm{~S}_{10}$ & 10 & 30 & 20 & 23,82 & 71,43 \\
\hline 11. & $\mathrm{~S}_{11}$ & 13 & 27 & 14 & 30,96 & 64,23 \\
\hline 12. & $\mathrm{~S}_{12}$ & 14 & 31 & 17 & 33,34 & 73,81 \\
\hline 13. & $\mathrm{~S}_{13}$ & 11 & 29 & 18 & 26,20 & 69,05 \\
\hline 14. & $\mathrm{~S}_{14}$ & 15 & 31 & 16 & 35,72 & 73,81 \\
\hline 15. & $\mathrm{~S}_{15}$ & 17 & 31 & 14 & 40,48 & 73,81 \\
\hline 16. & $\mathrm{~S}_{16}$ & 20 & 31 & 11 & 47,62 & 73,81 \\
\hline 17. & $\mathrm{~S}_{17}$ & 13 & 29 & 16 & 30,96 & 69,05 \\
\hline 18. & $\mathrm{~S}_{18}$ & 14 & 34 & 20 & 33,34 & 80,95 \\
\hline 19. & $\mathrm{~S}_{19}$ & 18 & 40 & 22 & 42,86 & 95,24 \\
\hline 20. & $\mathrm{~S}_{20}$ & 23 & 35 & 14 & 54,76 & 83,33 \\
\hline 21. & $\mathrm{~S}_{21}$ & 10 & 30 & 20 & 23,82 & 71,43 \\
\hline
\end{tabular}

terhadap pembelajaran menggunakan media komik dapat dilihat pada tabel 3. Dari Tabel 3 diketahui bahwa persentase respon 30 orang siswa kelas XE SMA Negeri 7 Pontianak terhadap pembelajaran menggunakan media komik diperoleh tingkat persetujuan sebesar $95,83 \%$. 


\begin{tabular}{|c|c|c|c|c|c|c|}
\hline 22. & $\mathrm{~S}_{22}$ & 16 & 32 & 16 & 38,10 & 76,19 \\
\hline 23. & $\mathrm{~S}_{23}$ & 17 & 37 & 20 & 40,48 & 88,10 \\
\hline 24. & $\mathrm{~S}_{24}$ & 8 & 30 & 22 & 19,06 & 71,43 \\
\hline 25. & $\mathrm{~S}_{25}$ & 17 & 33 & 16 & 40,48 & 78,57 \\
\hline 26. & $\mathrm{~S}_{26}$ & 22 & 31 & 9 & 52,38 & 73,81 \\
\hline 27. & $\mathrm{~S}_{27}$ & 15 & 30 & 15 & 35,72 & 71,43 \\
\hline 28. & $\mathrm{~S}_{28}$ & 16 & 24 & 8 & 38,10 & 57,14 \\
\hline 29. & $\mathrm{~S}_{29}$ & 17 & 34 & 17 & 40,48 & 80,95 \\
\hline 30. & $\mathrm{~S}_{30}$ & 21 & 34 & 13 & 50 & 80,95 \\
\hline & $\begin{array}{l}\text { Jumla } \\
\text { h }\end{array}$ & 455 & 954 & 491 & 1083,5 & $\begin{array}{l}2271,3 \\
7\end{array}$ \\
\hline & $\begin{array}{l}\text { Rata- } \\
\text { rata }\end{array}$ & $\begin{array}{l}15,1 \\
2\end{array}$ & 31,8 & 16,37 & 36,12 & 75,71 \\
\hline & SD & 3,59 & 3,16 & 4,00 & & \\
\hline \multicolumn{7}{|c|}{ Keterangan: } \\
\hline
\end{tabular}

Tabel 3 Distribusi Respon Siswa.

\begin{tabular}{|c|c|c|c|c|c|c|c|c|}
\hline \multirow[t]{2}{*}{ No } & \multirow[t]{2}{*}{ Pertanyaan } & \multicolumn{4}{|c|}{ Tanggapan } & \multirow{2}{*}{$\begin{array}{l}\text { Skor } \\
\text { Total }\end{array}$} & \multirow{2}{*}{$\begin{array}{l}\text { Persentase } \\
(\%)\end{array}$} & \multirow{2}{*}{$\begin{array}{l}\text { Interpretasi } \\
\text { skor }\end{array}$} \\
\hline & & $\mathrm{S}$ & $\mathrm{CS}$ & CTS & TS & & & \\
\hline 1 & $\begin{array}{l}\text { Saya senang } \quad \begin{array}{l}\text { dengan } \\
\text { pembelajaran }\end{array} \text { dengan } \\
\text { menggunakan media komik }\end{array}$ & 29 & 1 & 0 & 0 & 119 & 100 & Sangat Kuat \\
\hline 2 & $\begin{array}{l}\text { Media komik yang digunakan } \\
\text { memudahkan saya untuk } \\
\text { memahami materi pelajaran ini }\end{array}$ & 29 & 1 & 0 & 0 & 119 & 100 & Sangat Kuat \\
\hline 3 & $\begin{array}{l}\text { Saya semakin bingung dengan } \\
\text { pemebelajaran ini }\end{array}$ & 0 & 0 & 7 & 23 & 113 & 100 & Sangat Kuat \\
\hline 4 & $\begin{array}{l}\text { Saya ingin kegiatan belajar } \\
\text { berikutnya dapat seperti metode } \\
\text { pembelajaran yang telah saya } \\
\text { ikuti ini }\end{array}$ & 25 & 5 & 0 & 0 & 115 & 100 & Sangat Kuat \\
\hline 5 & $\begin{array}{l}\text { Komik yang digunakan } \\
\text { menurut saya menarik }\end{array}$ & 27 & 3 & 0 & 0 & 117 & 100 & Sangat Kuat \\
\hline 6 & Saya bosan membaca komik ini & 0 & 0 & 4 & 26 & 116 & 100 & Sangat Kuat \\
\hline 7 & $\begin{array}{l}\text { Bahasa yang digunakan pada } \\
\text { komik mudah saya mengerti }\end{array}$ & 21 & 8 & 1 & 0 & 110 & 98,18 & Sangat Kuat \\
\hline 8 & $\begin{array}{l}\text { Bahasa yang digunakan dalam } \\
\text { komik sulit saya mengerti }\end{array}$ & 1 & 1 & 6 & 22 & 109 & 97,25 & Sangat Kuat \\
\hline 9 & $\begin{array}{l}\text { Pembelajaran ini membuat saya } \\
\text { senang belajar kimia }\end{array}$ & 23 & 7 & 0 & 0 & 113 & 100 & Sangat Kuat \\
\hline 10 & $\begin{array}{l}\text { Gambar pada komik menurut } \\
\text { saya menarik }\end{array}$ & 26 & 4 & 0 & 0 & 116 & 100 & Sangat Kuat \\
\hline 11 & $\begin{array}{l}\text { Saya dapat merasakan manfaat } \\
\text { dari penggunaan media komik } \\
\text { yang berupa gambar }\end{array}$ & 28 & 2 & 0 & 0 & 118 & 100 & Sangat Kuat \\
\hline \multicolumn{6}{|c|}{ Total Skor } & 1265 & \multicolumn{2}{|c|}{$95,83 \%$} \\
\hline
\end{tabular}

\section{PEMBAHASAN}

Berdasarkan hasil tes dari 30 orang siswa kelas kontrol terlihat hampir seluruh siswa mengalami peningkatan hasil belajar, hanya 1 orang siswa yang tidak mengalami peningkatan hasil belajar. Namun terdapat 6 siswa $(20 \%)$ yang tidak memenuhi standar Kriteria Ketuntasan Minimal pada materi ini 
(KKM 63). Ketidaktuntasan hasil belajar siswa tersebut disebabkan karena kekurangseriusan siswa saat melaksanakan praktikum. Dilihat dari lembar hasil jawaban siswa, sebagian besar siswa tidak bisa menuliskan perbedaan antara larutan elektrolit dan nonelektrolit. Padahal pada saat praktikum terlihat jelas perbedaan kedua larutan tersebut.

Untuk mengetahui lebih lanjut penyebab ketidaktuntasan hasil belajar siswa di kelas kontrol, maka dilakukan wawancara terhadap siswa tersebut. Dari hasil wawancara terhadap siswa yang bersangkutan, di dapat alasan yang berbeda dari masing-masing siswa. Terdapat 2 orang siswa yang mengatakan tidak memperhatikan dengan benar hasil uji larutan elektrolit dan nonelektrolit yang dilakukan saat praktikum, 3 siswa beralasan mereka tidak sempat belajar sebelum posttset dilaksanakan, dan 1 siswa lainnya mengatakan tidak enak badan saat praktikum dilaksanakan. Dari hasil wawancara dengan guru bidang studi kimia SMA Negeri 3 Pontianak di dapat informasi bahwa, satu orang siswa yang tidak tuntas pada materi ini merupakan siswa yang tergolong nakal di kelas, sedangkan 3 siswa lainnya merupakan siswa yang mempunyai kemampuan kurang pada hampir semua mata pelajaran.

Berdasarkan hasil tes 30 orang siswa kelas eksperimen terlihat bahwa seluruh siswa mengalami peningkatan hasil belajar. Namun, hanya 1 orang siswa $(3,33 \%)$ yang tidak memenuhi Kriteria Ketuntasan Minimal pada materi ini. Dilihat dari hasil jawaban siswa tersebut pada posttest, terlihat bahwa siswa terlihat mengalami kesalahan dalam membedakan antara elektrolit kuat dan elektrolit lemah dan menjelaskan mengapa larutan garam bisa menghantarkan listrik sedangkan alkohol tidak. Berdasarkan hasil wawancara terhadap siswa tersebut diketahui bahwa siswa tersebut tidak senang membaca komik, sehingga ia tidak berminat untuk membaca kembali komik sebelum dilakukan posttest.

Tingginya tingkat ketuntasan siswa serta besarnya rata-rata peningkatan hasil belajar siswa sebelum dan sesudah perlakuan $(16,37)$ di kelas eksperimen, disebabkan karena pembelajaran menggunakan media komik membuat siswa senang belajar. Media komik juga memudahkan siswa untuk memahami materi. Gambar komik dan bahasa yang digunakan juga membuat siswa merasa nyaman dalam belajar. Hal ini diperkuat lagi dengan hasil angket yang diberikan kepada 30 orang siswa, 8 item yang menyatakan respon positif memiliki interpretasi sangat kuat, artinya hampir seluruh siswa menyatakan setuju dengan 8 item respon positif pada angket. Sedangkan 3 item respon negatif memiliki iterpretasi lemah, artinya siswa tidak setuju dengan 3 item respon negatif pada angket. Ini membuktikan adanya ketertarikan dan rasa senang pada siswa dalam mengikuti pembelajaran menggunakan media komik, sehingga adanya korelasi terhadap meningkatnya hasil belajar siswa.

Untuk mengetahui seberapa besar pengaruh pembelajaran materi larutan elektrolit dan nonelektrolit menggunakan media komik dapat diketahui dari harga Effect Size. Dari 
hasil perhitungan diperoleh harga Effect Size sebesar 1,82 diklasifikasikan tinggi. Hal ini menunjukkan bahwa pembelajaran dengan menggunakan media komik memiliki pengaruh yang sedang terhadap hasil belajar siswa kelas $\mathrm{X}$ SMA Negeri 3 Pontianak pada materi larutan elektrolit dan nonelektrolit. Merujuk ke tabel luas di bawah lengkung normal standar diperoleh nilai 0,4656. Dengan demikian persentase peningkatan hasil belajar siswa karena pengaruh pembelajaran menggunakan media komik sebesar 46,56 \%.

Berdasarkan deskripsi respon siswa terhadap pembelajaran menggunakan media komik, maka dapat diketahui bahwa siswa senang dan mempunyai tanggapan yang positif terhadap pembelajaran menggunakan media komik dengan tingkat persetujuan $95,83 \%$. Hal ini disebabkan karena mereka melakukan proses pembelajaran yang berbeda dari biasanya. Materi pembelajaran dibuat dalam bentuk komik dimana komik merupakan sesuatu yang mereka senangi dan minati.

\section{SIMPULAN DAN SARAN}

Berdasarkan hasil tindakan dan data yang diperoleh dari angket dan tes hasil belajar dapat ditarik kesimpulan sebagai berikut :1) Terdapat perbedaan hasil belajar antara siswa yang diberikan pembelajaran materi larutan elektrolit dengan menggunakan media komik dengan siswa yang diberikan pembelajaran dengan metode praktikum, 2) Berdasarkan menunjukkan bahwa pembelajaran materi larutan elektrolit dan nonelektrolit menggunakan media komik memberikan pengaruh yang tinggi sebesar 46,56 \% dalam meningkatkan hasil belajar siswa. 3) Respon 30 siswa kelas XE SMA Negeri 3 Pontianak terhadap pembelajaran materi larutan elektrolit dan nonelektrolit menggunakan media komik diperoleh tingkat persetujuan sebesar $95,83 \%$. Dari penelitian yang telah dilakukan, terdapat beberapa temuan yang dapat dijadikan sebagai saran dalam rangka pengembangan pengajaran kimia di sekolah menengah.

Adapun saran-saran dalam penelitian ini sebagai berikut :1) Pembelajaran menggunakan media komik dapat meningkatkan hasil belajar siswa, maka diharapkan para guru dapat mengembangkannya sebagai alternatif dalam pembelajaran kimia. 2) Dalam menggambarkan komik perlu diperhatikan lagi korelasi antara gambar dan materi yang akan disampaikan sehingga akan lebih mudah diterima oleh siswa, 3) Jika menggunakan media komik sebagai media pembelajaran, maka guru juga harus menjelaskan kembali materi yang ada di komik sehingga lebih jelas, untuk menghindari kesalahpahaman siswa dalam memahami isi komik.

\section{DAFTAR PUSTAKA}

Arifin. (1995). Pengembangan Program Pengajaran Kimia. Surabaya : Universitas Airlangga

Akhmad Sadiman dkk. (2006). Media Pendidikan Pengertian, Pengembangan 
dan Pemanfaatannya. Jakarta: PT Raja Grafindo Persada

Azhar A. (2006). Media Pembelajaran. Jakarta: PT Raja Grafindo Persada

Budi Prasetyo dkk. (2005). Metode Penelitian Kuantitatif Teori dan Aplikasi. Jakarta : PT Raja Grafindo Persada

Djamarah dkk. (2006). Strategi Belajar Mengajar. Bandung: PT Rineka Cipta

Emy Julianty. (2007). (Tidak diterbitkan). Efektifitas

Pembelajaran Menggunakan Media Komik pada Sub Pokok Bahasan LayangLayang di Kelas II SMP Negeri 1 Jawai. Pontianak : Universitas Tanjungpura

Hadari Nawawi. (2005). Metode Penelitian Bidang Sosial. Yogyakarta : Gadjah Mada University Press. (2003). Metode Penelitian Bidang Sosial. Yogyakarta : Gadjah Mada University Press.

Hamalik. (1999).

Media

Pendidikan. Bandung: PT Citra Aditya Bakti

Hurlock, E.B.

(2000).

Perkembangan

Anak.

(Penterjemah:

Meitasari

Tjandrasa dan Muslichah

Zarkasih). Jakarta: Erlangga.

Muhammad Iksan. (2006). Buku

Terlarang Itu Bernama

Komik.

[Http://muhamadikhsan.multipl y.com]

Nazir. (1998). Metodelogi

Penelitian. Jakarta: Ghalia Indonesia

Rahmat Satria. (2008). Hiburan vs

Pendidikan?, http://ksatria11.wordpress.com.

Akses 15 November 2008

Sagala (2005). Konsep dan Makna

Pembelajaran Cetakan Ke-3.

Bandung: CV Alfabeta

Scott McCloud. (2001). Understanding Comic.

Jakarta: Kepustakaan Populer.

Sugiono. (2008). Metode Penelitian

Administrasi. Bandung:

Alfabeta

Suharsimi Arikunto. (2006).

Prosedur Penelitian Suatu

Pendekatan Praktik Edisi

Revisi VI. Jakarta : PT Rineka Cipta.

Sutrisno. (2002). Metodelogi

Research. Yogyakarta: Andi Offset.

Syaiful Hadi. (2005). Pembelajaran Penjumlahan dan

Pengurangan Pecahan

dengan Menggunakan Media

Komik Pada Siswa Kelas III

SD Muhammadiyah Dau

Malang. Tesis tidak diterbitkan. Malang: Progran Pasca Sarjana UM.

. (2008). Pembelajaran

Konsep Pecahan

Menggunakan Media Komik

Dengan Strategi Bermain

Peran Pada Siswa SD Kelas

IV

Semen

Gresik.[http://www.puslitjak

nov.depdiknas.go.id/data/file/

2008/makalah peserta/57 $\mathrm{Sy}$

aiful\%20Hadi.pdf]

Syukri. S. (1999). Kimia Dasar I. Bandung: Institut Teknologi Bandung.

Universitas Tanjungpura. (2007). Pedoman Penulisan Skripsi. Pontianak: Fakultas Keguruan dan Ilmu Pendidikan. 
Waluyanto HD. (2007). Komik Sebagai media Komunikasi Visual pembelajaran. Fakultas Seni dan Desain Universitas Kristen Petra [http://www.petra.ac.id]. Akses 10 November 2008

Winataputra,dkk. (2006). Strategi

Belajar Mengajar. Jakarta: Universitas Terbuka 1995. Strategi Belajar Mengajar. Jakarta: Universitas Terbuka

Wismono. J. (2007). Kimia dan Kecakapan Hidup Pelajaran Kimia untuk SMA/MA Kelas X. Jakarta: Ganeca Exact 
